\title{
International meeting on modern batteries $\mathrm{ABA}-10$
}

\author{
Marie Sedlaříková • Jiřŕ Vondrák
}

Received: 23 June 2010 /Revised: 20 August 2010 / Accepted: 20 August 2010 /Published online: 4 September 2010

(C) The Author(s) 2010. This article is published with open access at Springerlink.com

\begin{abstract}
Tenth annual meeting "Advanced Batteries and Accumulators ABA-10" was arranged in Brno in summer 2009
\end{abstract}

The International Meeting on Modern batteries ABA-10 took place in 2009 in Brno, one of largest cities of Czech Republic, under the auspices of the Faculty of Electrical Engineering and Communication Technologies, Brno Technical University. Its scope comprised modern aprotic batteries, i.e., mainly lithium batteries, and related electrochromic elements and supercapacitors. Some attention was also given to aqueous systems: lead-acid batteries and alkaline batteries, and not the least, hydrogen-oxygen fuel cells.

These fields of interest reflect the scientific research and development program of the Department of Technology of Brno Technical University. The scientists of this department are studying the mentioned topics extensively for more than 30 years. The meeting was organized jointly by the Department of Technology of Brno Technical University and the Institute of Inorganic Chemistry at Husinec-Řež, the home institution of one of the organizers (J.V.).

The topics of the conference can be grouped as follows: (i) non-aqueous and (ii) aqueous systems. Lithium systems dominate in non-aqueous research, where oxide cathodes and carbon anodes for lithium-ion batteries, and the investigation of gel polymer (better to say, composite polymer) electrolytes are currently the major research field of the department. Parallel to this, materials for electrochemical supercapacitors using aprotic electrolytes are also studied.

\section{Sedlaříková}

Institute of Electrotechnology, Faculty of Electrical Engineering and Communications, Brno Technical University,

Brno, Czech Republic

e-mail: sedlara@seznam.cz

J. Vondrák $(\bowtie)$

Institute of Inorganic Chemistry, Academy of Sciences, v.v.i., Husinec- ̌̌ež, Czech Republic

e-mail: vondrakj@iic.cas.cz
The aqueous systems involve some classical systems (mainly the lead-acid and the alkaline accumulators). Fuel cell problems were a minor part of our program in the year 2009. The research of $\mathrm{Ni}(\mathrm{OH})_{2}$-positive electrodes was initiated by our main sponsor, the company Bochemie ltd. Bohumín, Czech Republic, and it was considered as most important for our investigations.

The conference was sponsored by Bochemie ltd., the company Autolab (Netherlands), the Technical University of Brno, and H-TEST ltd. We are also thankful to The Electrochemical Society, Pennington, U.S.A.

Selected papers of the conference are published in this issue of the Journal of Solid State Electrochemistry. The program and the meeting abstracts can be found at www.aba-brno.cz.

In 2009, at the ABA-10, we had participants from 11 countries. At all ten ABA meetings, the participants came from 28 countries. Now we are preparing the $11^{\text {th }}$ meeting which will take place in 2010. In order to emphasize the importance of fuel cells, we have decided to add the letter " $F$ " to the name of the conference, and the meetings will thus be called "ABAF-xx", where" $x x$ " should this year be replaced by the series number "11" However, the scope of the meeting will not undergo any considerable change. Again, we plan publication of a special issue of the Journal of Solid State Electrochemistry, containing original papers and short communications, while longer papers (reviews) can be published in an issue of Transactions of Electrochemistry. The manuscripts should be sent to the journals before the deadline mentioned on our website.

The next meeting (ABAF-11) will be held in Brno from September 19th to 22nd, 2010 in the main building of the University. We cordially invite everybody who likes to contribute to the scientific program and who likes to enjoy the social program as well.

Open Access This article is distributed under the terms of the Creative Commons Attribution Noncommercial License which permits any noncommercial use, distribution, and reproduction in any medium, provided the original author(s) and source are credited. 